\title{
Pengaruh Kelas Kemiringan dan Posisi Lereng terhadap Ketebalan Lapisan Olah, Kandungan Bahan Organik, Al dan Fe pada Alfisol di Desa Gunungsari Kabupaten Tasikmalaya
}

\author{
Fetty Dwi Rahmayanti, Mahfud Arifin*, Ridha Hudaya, dan Apong Sandrawati \\ Departemen Ilmu Tanah dan Sumber Daya Lahan, Fakultas Pertanian, Universitas Padjadjaran \\ Jl. Raya Bandung-Sumedang KM 21 Jatinangor Indonesia 45363 \\ *Alamat korespondensi: mahfud.arifin@unpad.ac.id
}

\begin{abstract}
Effect of slope gradient and its position to plow depth layer, organic matter, $\mathrm{Al}$ and Fe contents in alfisol soil located at Gunungsari Village, Tasikmalaya Regency
\end{abstract}

This research was done to know the influence of slope gradient and its position to plow depth layer, organic matter, $\mathrm{Al}$ and $\mathrm{Fe}$ contents. This research was carried out January-March 2011. The research used survey method with descriptive comparative analysis with free physiographic approach based on land cover. Sampling technique was used a purposive stratified sampling. Soil sampel took from three slope gradients: $8-15 \%, 16-25 \%$ and $26-40 \%$ with three position of crest, middle and lower positions. The result showed that the gradient of slope and its position have influenced plow layer depth and content of iron but organic material and $\mathrm{Al}$ were not influenced. The highest of plow layer depth and content of iron were occured at 8-15\%, while the highest of content of $\mathrm{Al}$ and iron were occured at 16-25\%. Based on slope position, the thick of plow layer, the content of organic matter, Fe were occured highest in the lower position and $\mathrm{Al}$ was occured in the middle position.

Keywords: Slope, plow depth layer, organic matter, $\mathrm{Al}, \mathrm{Fe}$

\begin{abstract}
ABSTRAK
Penelitian ini dilakukan untuk mengetahui adanya pengaruh dari kelas kemiringan dan posisi lereng terhadap ketebalan lapisan olah, bahan organik, Al dan Fe. Penelitian dilakukan pada bulan Januari-Maret 2011 dengan menggunakan metode survai dan analisis deskriptif komparatif melalui pendekatan fisiografis secara bebas berdasarkan penampakan fisiografis lahan. Teknik sampling berdasarkan metode sampel pertimbangan dalam stratifikasi. Contoh tanah diambil dari tiga kelas kemiringan lereng : 8-15\%, 16-25\% dan 26-40\% dengan tiga posisi lereng yaitu posisi atas, posisi tengah dan posisi bawah. Hasil penelitian menunjukkan bahwa kemiringan dan posisi lereng berpengaruh terhadap ketebalan lapisan olah dan kandungan Fe sedangkan terhadap bahan organik dan kandungan $\mathrm{Al}$ tidak berpengaruh. Ketebalan lapisan olah dan bahan organik tertinggi dijumpai pada kemiringan lereng $8-15 \%$ sedangkan kandungan $\mathrm{Al}$ dan $\mathrm{Fe}$ tertinggi yaitu pada kemiringan lereng 16-25\%. Berdasarkan posisi lerengnya, ketebalan lapisan olah, bahan organik, kandungan $\mathrm{Fe}$ tertinggi dijumpai pada posisi lereng bawah sedangkan kandungan Al pada posisi lereng tengah.
\end{abstract}

Kata Kunci: Lereng, Ketebalan lapisan olah, Bahan organik, Al, Fe

\section{PENDAHULUAN}

Lahan merupakan sumber daya alam yang sangat penting untuk pengembangan usaha pertanian, terutama untuk memenuhi kebutuhan sandang dan pangan. Permasalahan dalam penggunaan lahan sifatnya umum di seluruh dunia, baik di negara sedang berkembang maupun di negara-negara maju, terutama dengan terjadinya peningkatan jumlah penduduk dan proses 
industrialisasi (Lamb et al.,, 2005). Menurut Bukart (2007), kualitas tanah menurun selain disebabkan oleh terjadinya pencemaran, juga disebabkan oleh erosi. Erosi dapat menyebabkan merosotnya produktivitas lahan, rusaknya lingkungan, terganggunya keseimbangan estetika, serta pencemaran lingkungan hidup. Kualitas tanah yang menurun juga dapat berakibat penurunan kualitas kandungan nutrisi pada tanaman yang ditanam (Lal, 2009).

Alfisol adalah tanah-tanah dimana terdapat penimbunan liat di horison bawah (horison argilik) dan mempunyai kejenuhan basa berdasar jumlah kation tinggi yaitu lebih dari 35\% pada kedalaman $180 \mathrm{~cm}$ dari permukaan tanah (Hardjowigeno, 2003). Topografi berperan dalam menentukan kecepatan dan volume limpasan lapisan permukaan. Dua unsur topografi yang berpengaruh terhadap erosi adalah panjang lereng dan kemiringan lereng (Arsyad, 1989). Semakin panjang lereng, maka volume kelebihan air yang berakumulasi di atasnya menjadi lebih besar dan kemudian semua akan turun dengan volume dan kecepatan yang meningkat. Menurut Arsyad (1989), tanah di bagian bawah lereng mengalami erosi yang lebih besar daripada di bagian atas lereng, karena semakin ke bawah, air yang terkumpul semakin banyak dan kecepatan aliran juga meningkat, sehingga daya erosi besar. El-Swaify (1997) menyatakan bahwa kehilangan tanah akibat erosi di lahan miring dapat mencapai ratusan ton hektar per tahun.

Perkembangan perakaran tanaman paling banyak terletak di lapisan olah atau lapisan atas tanah sampai kedalaman $15-30 \mathrm{~cm}$ yang mengandung paling banyak bahan organik (Pusat Penelitian Tanah dan Agroklimat, 1993). Kebanyakan tanaman semusim sistem perakarannya terletak di lapisan atas tanah setebal $20-30 \mathrm{~cm}$, sedang tanaman tahunan mempunyai perakaran yang lebih dalam. Lapisan atas tanah (lapisan olah) adalah bagian profil tanah yang lama mengalami pelapukan dan merupakan lapisan tanah yang paling subur.

Pembentukan kompleks organik dan produk sisa organik dipengaruhi oleh dekomposisi mikroba yang selanjutnya memengaruhi jumlah dan distribusi bahan organik di Alfisol. Kandungan bahan organik Alfisol dan ketebalan horizon permukaan meningkat dengan menurunnya drainase interal dan aerasi tanah. Bahan organik tanah merupakan hasil pelapukan sisa-sisa tanaman atau tumbuh-tumbuhan atau binatang yang bercampur dengan bahan mineral tanah pada lapisan atas tanah
(Pusat Penelitian Tanah dan Agroklimat, 1993). Bahan organik dalam tanah terdiri dari bahan organik kasar dan bahan organik halus atau humus.

Mineral-mineral oksida umumnya banyak terdapat pada tanah-tanah tua di daerah topika misalnya tanah Oksisol dan tanah Ultisol dan pada tanah yang pelapukannya belum lanjut seperti Alfisol (Hardjowigeno, 2003). Pada tanah Alfisol kejenuhan $\mathrm{Al}$ nya tinggi serta $\mathrm{Fe}$ nya dapat menyebabkan racun bagi tanah (Cyio, 2008). Pergerakan dan perpindahan $\mathrm{Al}$ dan $\mathrm{Fe}$ dapat jelas terlihat pada tanah-tanah yang terletak pada kemiringan dan posisi lereng tertentu. Persenyawaan $\mathrm{Fe}$ dan $\mathrm{Al}$ umumnya tidak larut dalam air pada kisaran $\mathrm{pH}$ normal. Namun kelarutan bahan ini dapat ditingkatkan melalui pembentukan kompleks atau berlangsungnya proses khelat antara $\mathrm{Fe}$ dan $\mathrm{Al}$ dengan persenyawaan humat.

Asumsi berdasarkan pengamatan di lapangan bahwa lahan pada kemiringan 8-15\%, 16$25 \%, 26-40 \%$ yang menjadi tempat penelitian dan pengambilan sampel adalah lahan tegalan yang terdapat campur tangan manusia yang intens, karena sifat dari vegetasi yang berada di sekitar lokasi penelitian adalah termasuk tanaman musiman. Selain itu, kedalaman tanah yang diambil untuk pengambilan sampel adalah $15-25 \mathrm{~cm}$ dari permukaan tanah dengan tiga titik pengambilan sampel, yaitu pada posisi atas, posisi tengah dan posisi bawah lereng.

Berdasarkan uraian penjelasan di atas bahwa lapisan olah dari suatu tanah serta bahan organik dapat mempengaruhi satu sama lain begitu juga dengan $\mathrm{Al}$ dan $\mathrm{Fe}$ dari suatu tanah yang sebagian besar dipengaruhi oleh kemiringan dan posisi suatu lereng. Selain itu kemiringan dan posisi lereng satu sama lain dapat memberikan interaksi yang menunjukkan keeratan pengaruh dari kemiringan dan posisi lereng terhadap ketebalan lapisan olah, bahan organik, $\mathrm{Al}$ dan Fe.

\section{BAHAN DAN METODE}

Penelitian dilaksanakan pada bulan Januari sampai dengan Maret 2011 di Desa Gunungsari Kecamatan Cikatomas, Kabupaten Tasikmalaya, Jawa Barat. Lokasi penelitian ini terletak pada ketinggian $309 \mathrm{~m}$ di atas permukaan laut yang memiliki luas wilayahnya 2.494 .490 ha. Penelitian ini difokuskan pada lahan tegalan, luas lahan tegalannya 683,370 ha dan pada kemiringan lereng $8-15 \%, 16-25 \%$ dan $26-40 \%$ serta topografi datar, 
berombak sampai curam dengan panjang lereng berkisar antara 35-100 m. Temperatur rata-ratanya yaitu $26^{\circ} \mathrm{C}$. Analisis laboratorium dilakukan di Laboratorium Kimia dan Kesuburan Tanah Fakultas Pertanian Universitas Padjadjaran dan di Laboratorium Tanah Pusat Penelitian dan Pengembangan Tanah dan Agroklimat, Bogor yang meliputi analisis bahan organik, Al dan Fe tanah.

Metode yang digunakan pada penelitian ini adalah metode survai dan analisis deskriptif komparatif melalui pendekatan fisiografik (physiography approach) secara bebas berdasarkan penampakan fisiografis lahan yaitu kemiringan lereng dan jenis tanah. Menurut Abdullah (1997), metode bebas atau metode satuan lahan merupakan metode survai dengan pengamatan berdasarkan satuan lahan yang telah dibuat dan dicek kebenarannya. Teknik sampling berdasarkan metode sampel pertimbangan dalam stratifikasi (purposive stratified sampling). Dasar metode ini menurut (Mantra \& Kasto, 1982 dalam Sumartoyo, 1989) disebutkan bahwa purposive sampling merupakan metode pengambilan sampel berdasarkan pertimbangan tertentu, yaitu kompleksnya lahan, luasnya areal pada setiap satuan lahan, waktu dan kemudahan pencapaian lokasi. Satuan lahan dipilih sebagai strata yang dianggap mempunyai unsurunsur yang seragam atau relatif seragam.

Pengambilan contoh tanah yang dilakukan sacara transek pada lereng yang sama tanpa memperhitungkan jarak antar titik pengamatan. Kemiringan lereng yang diamati yaitu pada kemiringan $8-15 \%$, 15-25\%, 25-40\% dan posisi lerengnya meliputi posisi atas, posisi tengah dan posisi bawah. Pada setiap kemiringan dan posisi lerengnya dilakukan tiga kali ulangan pengambilan sampel sehingga didapatkan 27 sampel data.

Pengambilan contoh tanah yang dilakukan sacara transek pada lereng yang sama tanpa memperhitungkan jarak antar titik pengamatan. Kemiringan lereng yang diamati yaitu pada kemiringan $8-15 \%, \quad 15-25 \%$, 25-40\% dan posisi lerengnya meliputi posisi atas, posisi tengah dan posisi bawah. Pada setiap kemiringan dan posisi lerengnya dilakukan tiga kali ulangan pengambilan sampel sehingga didapatkan 27 sampel data. Penelitian ini mencakup empat tahapan kegiatan yaitu persiapan, survei dan pengambilan sampel, analisis laboratorium serta interpretasi data lapangan dan hasil analisis laboratorium, artinya tidak ada perlakuan dalam penelitian ini yang dirancang secara eksperimental statistik (penelitian ini merupakan penelitian non eksperimental).
Untuk mengetahui perbedaan ketebalan lapisan olah tanah, kandungan bahan organik, Fe dan $\mathrm{Al}$ tanah, akibat perbedaan tingkat kemiringan dan posisi lereng maka digunakan analisis histogram, sedangkan untuk mengetahui derajat keeratan antara sifat-sifat tanah yang diamati dilakukan uji korelasi dan regresi. Data-data hasil pengamatan kemiringan lereng dikelompokkan berdasarkan kombinasi dari klasifikasi kelas kemiringan lereng (Meijerink, 1988; USDA, 1993 dalam Abdullah, 1996). Klasifikasi kelas kemiringan lereng dapat dilihat pada Tabel 1 dan digunakan dalam analisis hubungan kemiringan lereng terhadap ketebalan lapisan olah, bahan organik, $\mathrm{Al}$ dan Fe tanah.

Metode korelasi yang digunakan adalah sidik korelasi linear sederhana yaitu untuk pendugaan dan uji beda nyata koefisien korelasi linear sederhana $r$, yang merupakan ukuran derajat hubungan linear antara dua peubah $\mathrm{X}$ dan $\mathrm{Y}$. Persamaan korelasi adalah sebagai berikut:

$$
\mathrm{r}=\frac{\sum x y}{\sqrt{\left(\sum x^{2}\right)\left(\sum y^{2}\right)}}
$$

\section{Keterangan:}

$\mathrm{r} \quad=$ Koefisien korelasi

$\sum x y=$ Jumlah hasil kali terkoreksi

$\sum x^{2}$ dan $\sum y^{2}=$ Jumlah kuadrat terkoreksi

Koefisien korelasi linear sederhana diuji dengan membandingkan nilai $r$ hitung dengan nilai $r$ table dengan derajat bebas $(\mathrm{n}-2)$. Koefisien korelasi linear sederhana dinyatakan berbeda nyata yaitu semakin curam dan semakin atas posisi lereng, persentase ketebalan lapisan olah, bahan organik, Al dan Fe tanah lebih rendah pada taraf nyata $\alpha$ apabila nilai absolut dari $r$ hitung $>r$ table pada taraf $\alpha$.

Metode regresi yang digunakan adalah regresi linier yaitu dengan mengamati diagram pencar yang mengikuti suatu garis lurus, menunjukkan bahwa kedua peubah tersebut saling berhubungan secara linier yang dinyatakan secara matematik dengan sebuah persamaan garis lurus, yaitu:

$y=a+b x$

Keterangan:

$\mathrm{a}=$ intersep atau perpotongan dengan sumbu tegak

$\mathrm{b}=$ kemiringan atau gradiennya

$\mathrm{y}=$ pembeda nilai ramalan yang dihasilkan garis regresi dan nilai pengamatan y yang sesungguhnya untuk nilai $\mathrm{x}$ tertentu 


\section{HASIL DAN PEMBAHASAN}

Hasil survei dan pengamatan lapangan menunjukkan, penggunaan lahan di Desa Gunungsari, Kabupaten Tasikmalaya ini didominasi oleh penggunaan lahan untuk lahan sawah dan untuk lahan kering (Tabel 1). Pada penelitian ini digunakan penggunaan lahan berupa tegalan yang didominasi oleh tanaman semusim seperti umbiumbian, kacang-kacangan, cabai dan palawija.

Tabel 1. Penggunaan lahan untuk (tanah sawah, tanah kering dan tanah basah) di Desa Gunungsari

\begin{tabular}{clc}
\hline No. & Jenis penggunaan lahan & Total luas $(\mathrm{Ha})$ \\
\hline 1 & Sawah Irigasi 1/2 Teknis & 27,570 \\
2 & Sawah Tadah Hujan & 245,115 \\
3 & Tegalan / Ladang & 683,370 \\
4 & Pemukiman & 32,144 \\
5 & Pekarangan & 10,670 \\
6 & Cek Dam & 1000 \\
\hline
\end{tabular}

Sumber: Data Desa Gunungsari, Kabupaten Tasikmalaya JawaBarat (2011)

Berdasarkan deskripsi profil lokasi daerah penelitian, tanah ini termasuk kedalam ordo Alfisol. Hal ini diperkuat dengan adanya data-data hasil survei, bahwa tanahnya terdapat horison Bt yang artinya pada horison B memiliki akumulasi liat yang tinggi dan terdapat horison argilik yang merupakan penciri bahwa tanah tersebut tergolong ordo Alfisol. Selain itu berdasarkan data dari peta geologi termasuk kedalam bahan induk anggota batu gamping formasi pamutuan. Tanah berwarna coklat kemerahan dan terdapat sedikit karatan kecil-kecil berbaur dengan batas peralihan horisonnya dari horison atas ke bawah nyata dan rata.

Pada hasil pengukuran KTK tanah didapatkan bahwa rata-rata KTK tanah pada posisi lereng atas $27,99 \mathrm{cmol} / \mathrm{kg}$, posisi lereng tengah 22,71 $\mathrm{cmol} / \mathrm{kg}$ dan posisi lereng bawah $20,67 \mathrm{cmol} / \mathrm{kg}$. Menurut (Hardjowigeno, 2003) Alfisol mempunyai kapasitas tukar kation tinggi, kejenuhan basa tinggi dan cadangan unsur hara tinggi, sehingga dapat disimpulkan bahwa tanah ini termasuk ke dalam ordo Alfisol. Pada kedalaman lapisan 39-90 cm terdapat horison penciri argilik dengan kandungan liat yang sangat tinggi. Pada tanah ini juga banyak ditemukan konkresi $\mathrm{Fe}$, Ca dan $\mathrm{Mn}$, yang terdapat mulai di lapisan atas (Ap1) hingga pada lapisan $B t_{1}$. Selain itu pada tanah ini juga banyak ditemukan karatan (motles) yang menandakan bahwa tanah ini banyak mengandung Fe yang tinggi.

Subordo dari ordo Alfisol ini adalah Udalfs, karena tanah ini tergolong humid dan terdapat karatan langsung di bawah horison A. Pada pengukuran $\mathrm{pH}$ tanah didapatkan bahwa rata-rata $\mathrm{pH}$ tanah pada lokasi penelitian berkisar antara 5,35,9 yang menandakan bahwa tanah ini tergolong tanah yang agak masam, $\mathrm{pH}$ yang demikian menurut (Hardjowigeno, 2003) bahwa $\mathrm{pH}$ yang berkisar antara 5,3-6,5 ada exchange acidity, yang mungkin berasal dari hidroksi $\mathrm{Al}$ atau gugus fungsional dari bahan organik.

Desa Gunungsari terletak pada ketinggian 309 di atas permukaan laut, yang secara umum kondisi topografinya bervariasi mulai dari datar, bergelombang, berbukit sampai bergunung dengan kemiringan lahan rata-rata 8-70\%. Pengambilan sampel dilakukan pada kisaran kemiringan 8-15\%, $16-25 \%$ dan $26-40 \%$ yang penggunaan lahannya berupa tegalan tanpa adanya tindakan konservasi. Menurut Peta Geologi Lembar Karangnunggal (2010) daerah penelitian termasuk ke dalam kode bahan induk Tmpl, yaitu anggota batu gamping formasi pamutuan (limestone member pamutuan formation) yang tergolong ke dalam anggota batugamping formasi pamutuan yaitu batugamping pasiran, kalsilutit dan napal.

Keadaan curah hujan tahunan di desa Gunungsari, Kecamatan Cikatomas sebesar 3500$4000 \mathrm{~mm} / \mathrm{tahun}$. Berdasarkan data curah hujan selama kurun waktu 10 tahun (1998-2007) yang didapatkan menunjukkan bahwa daerah Gunungsari memiliki jumlah rata-rata bulan kering sebesar 2,7 sedangkan bulan basah sebesar 8,7. Berdasarkan jumlah rata-rata bulan kering dan bulan basah tersebut maka daerah Gunungsari tergolong curah hujan tipe B yaitu basah menurut klasifikasi Schmidt-Ferguson dengan nilai Q adalah 0.310.

Perhitungan rata-rata ketebalan lapisan olah pada kemiringan 8-15\% menunjukkan nilai ratarata tertinggi yaitu sebesar $25,1 \mathrm{~cm}$ sedangkan pada kemiringan lereng 16-25 \% dan 26-40\% memiliki nilai rata-rata $20,1 \mathrm{~cm}$ dan $18,4 \mathrm{~cm}$ (Tabel 2).

Tabel 2. Rata-rata ketebalan lapisan olah (cm) pada berbagai kemiringan lereng

\begin{tabular}{cc}
\hline Kemiringan (K) & $\begin{array}{c}\text { Rata-rata ketebalan lapisan olah } \\
(\mathrm{cm})\end{array}$ \\
\hline I (8-15\%) & 25,1 \\
II (16-25\%) & 20,1 \\
III (26-40\%) & 18,4 \\
\hline
\end{tabular}


Nilai koefisien korelasi terhadap ketebalan lapisan olah sebesar $(r=-0,964)$ untuk kemiringan lereng $8-15 \%,(\mathrm{r}=-0,965)$ untuk kemiringan lereng $16-25 \%$ dan $(r=-0,25)$ untuk kemiringan lereng 26$40 \%$. Hasil uji korelasi terhadap ketebalan lapisan olah diperoleh nilai koefisien determinasi lapisan olah pada kemiringan lereng $8-15 \%\left(R^{2}=0,931\right), 16$ $25 \%\left(R^{2}=0,932\right)$ dan $26-40 \%$ sebesar $\left(R^{2}=0,062\right)$, artinya bahwa 93,1\%, 93,2\% dan 62\% ketebalan lapisan olah dipengaruhi oleh kemiringan dan posisi lereng sedangkan sisanya dipengaruhi faktor lain seperti jenis vegetasi yang berada di sekitar lokasi penelitian, kandungan bahan organik dan faktor manusia. Ketebalan lapisan olah juga dipengaruhi oleh kandungan bahan organik (Gambar 1).

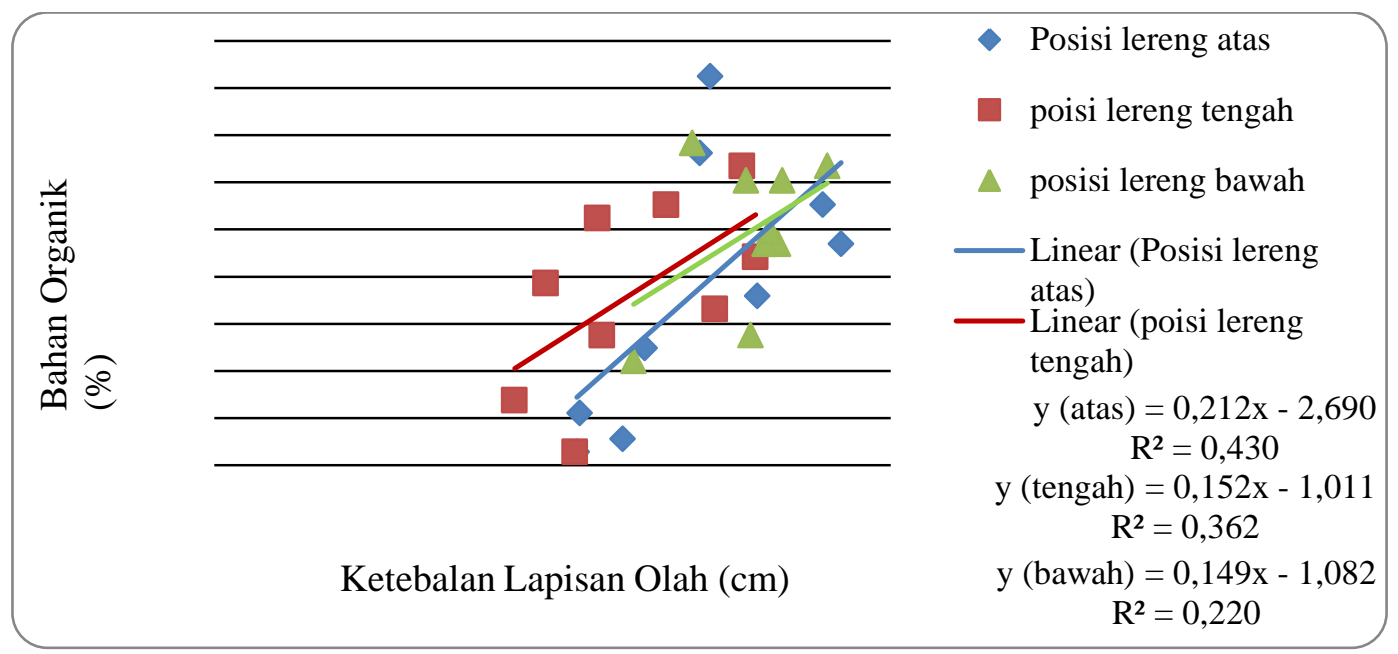

Gambar 1. Hubungan ketebalan lapisan olah dengan bahan organik pada berbagai posisi lereng

Dari hasil perhitungan rata-rata ketebalan lapisan olah, posisi lereng bawah memiliki ketebalan lapisan olah yang paling tinggi yaitu sebesar $23,7 \mathrm{~cm}$ rata-ratanya dibandingkan dengan posisi lereng atas dan tengah sebesar $21,3 \mathrm{~cm}$ dan $18,6 \mathrm{~cm}$ (Tabel 3). Hal ini dikarenakan daerah lokasi penelitian memiliki curah hujan yang cukup tinggi dan memudahkan air hujan masuk dan tersimpan didalam tanah sebagai air infiltrasi dan agregatagregat tanah yang bertekstur debu sangat mudah terbawa erosi terutama yang berada pada posisi lereng atas dan tengah. Menurut (Hardjowigeno, 2007) Horison A yang tebal umumnya terdapat di lereng cekung atau di tempat datar, sedangkan yang paling tipis adalah di lereng cembung.

Tabel 3. Rata-rata ketebalan lapisan olah (cm) pada berbagai posisi lereng

\begin{tabular}{lc}
\hline \multicolumn{1}{c}{ Posisi (P) } & $\begin{array}{c}\text { Rata-rata ketebalan lapisan olah } \\
(\mathrm{cm})\end{array}$ \\
\hline Atas & 21,3 \\
Tengah & 18,6 \\
Bawah & 23,7 \\
\hline
\end{tabular}

Hasil perhitungan rata-rata kandungan bahan organik pada kemiringan $8-15 \%, 16-25 \%$ dan
26-40\% adalah 2,49\%, 2,47\% dan 1,17\% (Tabel 4). Kemiringan lereng di lokasi penelitian tidak terlalu berpengaruh terhadap kandungan bahan organik dan juga berkorelasi negatif yang artinya dengan semakin meningkatnya kemiringan lereng maka ketebalan lapisan olahnya rendah. Tidak terlalu berpengaruhnya kemiringan lereng diperkirakan akibat adanya penggunaan lahan yang intensif oleh petani setempat yang menggunakan tanah untuk dijadikan media tanam bagi berbagai jenis tanaman dan kurangnya usaha-usaha untuk mengembalikan bahan organik sebagai sumber C-organik bagi tanah dan bagi fauna tanah terutama bagi mikroba tanah.

Tabel 4. Rata-rata bahan organik (\%) pada berbagai kemiringan lereng

\begin{tabular}{cc}
\hline Kemiringan $(\mathrm{K})$ & Rata-rata bahan organik (\%) \\
\hline I (8-15\%) & 2,49 \\
II (16-25\%) & 2,47 \\
III (26-40\%) & 1,17 \\
\hline
\end{tabular}

Pada posisi lereng bawah memiliki kandungan bahan organik lebih tinggi daripada posisi lereng atas dan tengah hal ini terjadi dikarenakan proses erosi yang cukup besar di lereng atas dan tengah yang menyebabkan sedimentasi 
bahan-bahan organik di lereng bawah. Faktor lain yang mempengaruhi kandungan bahan organik adalah tekstur tanah, iklim dan drainase. Tekstur tanah di lokasi penelitian secara umum didominasi oleh tekstur liat (clay), lempung (loam), lempung berliat (clay loam) dan lempung liat berdebu (silty clay loam). Semakin tinggi liat maka kandungan bahan organik pun semakin tinggi, karena bahan organik terdapat sebuah fraksi yaitu humus yang dapat bersifat koloid, dan liat itu sendiri mampu membentuk koloid anorganik yaitu koloid mineral pada tanah sehingga liat dan bahan organik samasama mampu membentuk koloid. Kandungan bahan organik pada posisi lereng dapat dilihat pada Tabel 5.

Tabel 5. Rata-rata bahan organik (\%) pada berbagai posisi lereng

\begin{tabular}{lc}
\hline \multicolumn{1}{c}{ Posisi (P) } & Rata-rata bahan organik (\%) \\
\hline Atas & 1,83 \\
Tengah & 1,83 \\
Bawah & 3,90 \\
\hline
\end{tabular}

Kandungan Al di lokasi penelitian lebih mendominasi pada kemiringan lereng yang cukup curam yaitu dengan kemiringan lereng $16-25 \%$ dan kemiringan lereng 26-40\% (Tabel 6). Disebutkan bahwa pada keadaan basa-basa habis tercuci tinggallah kation $\mathrm{Al}$ dan $\mathrm{H}$ sebagai kation dominan yang menyebabkan tanah bereaksi masam, sehingga pada lereng bagian bawah memiliki $\mathrm{Al}$ yang tinggi (Haynes, 1986).

Tabel 6. Rata-rata $\mathrm{Al}(\mathrm{cmol} / \mathrm{kg})$ pada berbagai kemiringan lereng

\begin{tabular}{cc}
\hline Kemiringan $(\mathrm{K})$ & $\begin{array}{c}\text { Rata-rata kandungan Al } \\
(\mathrm{cmol} / \mathrm{kg})\end{array}$ \\
\hline I (8-15\%) & 1,28 \\
II (16-25\%) & 4,03 \\
III (26-40\%) & 2,20 \\
\hline
\end{tabular}

Pada penelitian ini Al dapat terukur dan dipengaruhi oleh sedimentasi dan transpor material dari batuan sedimen yang kaya akan Al karena lokasi penelitian memiliki panjang lereng yang sangat panjang di lereng bagian atasnya. Dengan demikian, sedimentasi dan transpor material dari batuan sedimen ke bagian lereng dibawahnya tidak dapat dihindarkan yang menyebabkan terdapat kandungan $\mathrm{Al}$ pada lokasi penelitian tersebut, terutama di posisi lereng bagian bawah kandungan Al lebih tinggi dibandingkan dengan posisi lereng atas dan tengah (Tabel 7).
Tabel 7. Rata-rata $\mathrm{Al}(\mathrm{cmol} / \mathrm{kg})$ pada berbagai posisi lereng

\begin{tabular}{lc}
\hline \multicolumn{1}{c}{ Posisi $(\mathrm{P})$} & $\begin{array}{c}\text { Rata-rata kandungan } \mathrm{Al} \\
(\mathrm{cmol} / \mathrm{kg})\end{array}$ \\
\hline Atas & 2,01 \\
Tengah & 3,82 \\
Bawah & 1,6 \\
\hline
\end{tabular}

Dari hasil perhitungan rata-rata dan analisis histogram kandungan $\mathrm{Fe}$ tanah pada berbagai kemiringan lereng yaitu pada kemiringan lereng 8$15 \%, 16-25 \%$ dan $26-40 \%$, pada kemiringan lereng $16-25 \%$ dan pada posisi tengah yang paling memberikan pengaruh (Tabel 8). Kandungan $\mathrm{Fe}$ banyak terdapat pada kemiringan $16-25 \%$ dan 8$15 \%$ dibandingkan dengan kemiringan 26-40\% artinya bahwa semakin curam lereng kandungan $\mathrm{Fe}$ semakin rendah dan sebaliknya semakin landai lereng kandungan Fe semakin tinggi.

Tabel 8. Rata-rata Fe (ppm) pada berbagai kemiringan lereng

\begin{tabular}{cc}
\hline Kemiringan (K) & $\begin{array}{c}\text { Rata-rata Kandungan Fe } \\
(\mathrm{ppm})\end{array}$ \\
\hline I (8-15\%) & 3,86 \\
II (16-25\%) & 3,90 \\
III (26-40\%) & 2,37 \\
\hline
\end{tabular}

Pengaruh kemiringan dan posisi lereng terhadap kandungan $\mathrm{Fe}$ menunjukan koefisien korelasi dengan arah negatif artinya semakin tinggi kandungan $\mathrm{Fe}$ tanah maka semakin landai kemiringan lereng. Korelasi yang terjadi antara kemiringan dan posisi lereng terhadap $\mathrm{Fe}$ adalah kuat. Hubungan bahan organik dengan kandungan Fe pada berbagai posisi lereng dapat dilihat pada Gambar 2.

Selain itu jenis bahan induk juga dapat mempengaruhi kandungan $\mathrm{Fe}$ tanah dan dari drainase yang ada, karena bahan induknya merupakan batu gamping yang termasuk kedalam golongan kapur yang sifatnya mudah mengalami sedimentasi dan mudah larut dalam air. Jika tanah selalu dalam keadaan tergenang menyebabkan besi ditanah dalam keadaan reduksi sedangkan dalam keadaan tidak tergenang besi dalam keadaan oksidasi, biasanya perubahan keadaan reduksi dan oksidasi ini sering terlihat secara langsung pada warna tanah.

Kandungan $\mathrm{Fe}$ lebih tinggi dikarenakan akibat pencucian (leaching) yang berlangsung terus menerus dan adanya aliran permukaan (run off) 
yang mengakibatkan hilangnya Fe dari solum tanah yang mengangkutnya ke lereng bagian bawahnya yang lebih landai, karena menurut deret Polynov Fe memiliki sifat yang lebih mobil sehingga banyak terdapat $\mathrm{Fe}$ di posisi bagian bawah. Kandungan $\mathrm{Fe}$ pada berbagai posisi lereng dapat dilihat pada Tabel 9.

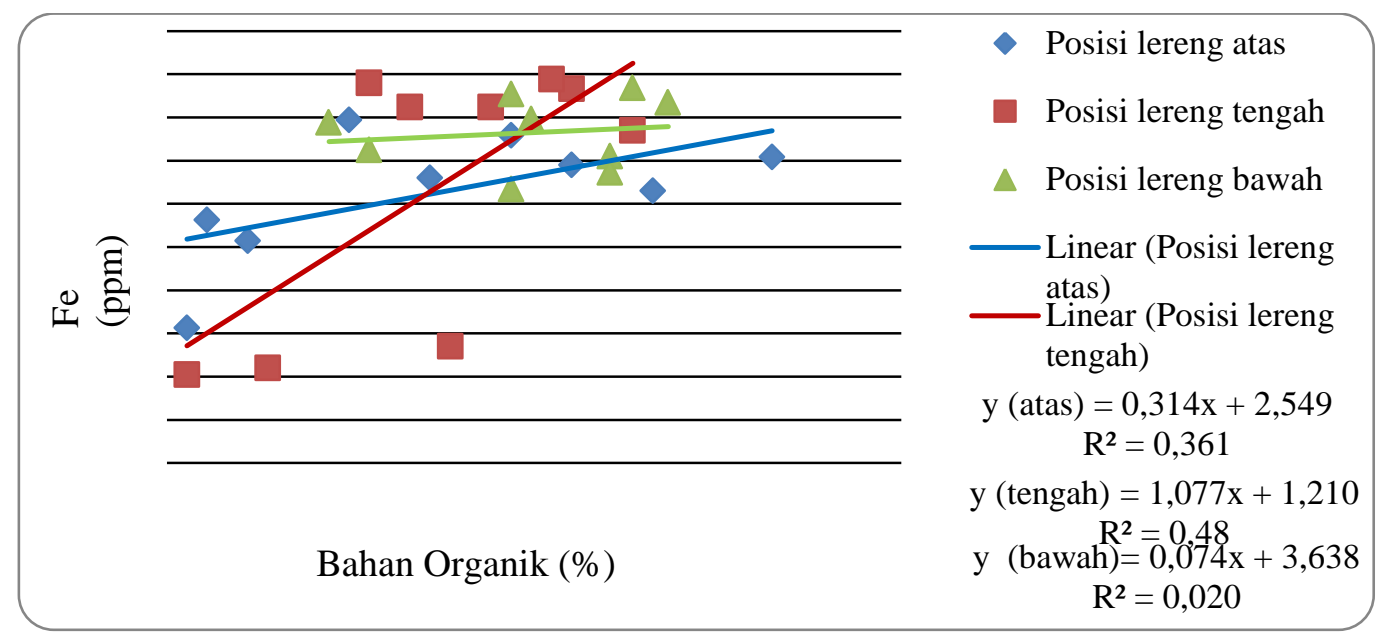

Gambar 2. Hubungan bahan organik dengan kandungan Fe pada berbagai posisi lereng

Tabel 9. Rata-rata Fe (ppm) pada berbagai posisi lereng

\begin{tabular}{lc}
\hline \multicolumn{1}{c}{ Posisi $(\mathrm{P})$} & Rata-rata kandungan Fe $(\mathrm{ppm})$ \\
\hline Atas & 3,12 \\
Tengah & 3,19 \\
Bawah & 3,82 \\
\hline
\end{tabular}

\section{SIMPULAN DAN SARAN}

\section{Simpulan}

1. Kemiringan dan posisi lereng berpengaruh terhadap ketebalan lapisan olah dan kandungan Fe sedangkan terhadap bahan organik dan kandungan Al tidak berpengaruh.

2. Ketebalan lapisan olah dan kandungan bahan organik tertinggi pada kemiringan lereng 8-15\%, yaitu $25,1 \mathrm{~cm}$ dan 2,49\% serta ketebalan lapisan olah dan kandungan bahan organik tertinggi pada posisi lereng bawah, yaitu $23,7 \mathrm{~cm}$ dan $3,9 \%$.

3. Kandungan $\mathrm{Al}$ dan $\mathrm{Fe}$ tertinggi pada kemiringan lereng $16-25 \%$, yaitu $4,03 \mathrm{cmol} / \mathrm{kg}$ dan $3,9 \mathrm{ppm}$ serta kandungan $\mathrm{Al}$ dan Fe tertinggi pada posisi lereng tengah dan bawah, yaitu $3,82 \mathrm{cmol} / \mathrm{kg}$ dan 3,82 ppm.

\section{Saran}

1. Sebaiknya dilakukan penelitian yang serupa dengan lebih memperhatikan panjang lereng dan memperbanyak titik pengamatan agar didapatkan hasil yang lebih akurat.

2. Sebaiknya dilakukan penelitian yang serupa dengan melakukan analisis T-student untuk melihat perbedaan tiap posisi dan kemiringan lereng serta dilakukan penelitian terhadap parameter kejenuhan $\mathrm{Al}$ untuk melihat pengaruh kejenuhan Al terhadap erosi dan pedogenesis pada tanah.

\section{DAFTAR PUSTAKA}

Abdullah, TS. 1996. Teknik Survei dan Pemetaan Tanah Kategori Seri dalam Sistem Taksonomi Tanah. Jurusan Ilmu Tanah, Fakultas Pertanian Institut Pertanian Bogor. Bogor. Edisi Kedua.

Abdullah, TS. 1997. Penuntun Modul Praktikum Survei Tanah dan Evaluasi Lahan. Jurusan Ilmu Tanah, Fakultas Pertanian Institut Pertanian Bogor, Bogor.

Arsyad, S. 1989. Konservasi Tanah dan Air. Institut Pertanian Bogor Press, Bogor.

Bukart, MR. 2007. Diffuse pollution from intensive agriculture: sustainability, challenges, and opportunities. Water Science Technology 55 (3): 17-23.

Cyio, MB. 2008. Efektivitas bahan organik dan tinggi genangan terhadap perubahan $\mathrm{Eh}, \mathrm{pH}$, dan 
status $\mathrm{Fe}, \mathrm{P}, \mathrm{Al}$ terlarut pada tanah ultisol. Jurnal Agroland 15 (4): 257-263.

El-Swaify, SA. 1997. Factors affecting soil erosion hazards and conservation needs for tropical steeplands. Soil Technology 11 (1): 3-16.

Hardjowigeno, S. 2003. Klasifikasi Tanah dan Pedogenesis. Akademika Pressindo, Jakarta.

Hardjowigeno, S. 2007. Ilmu Tanah. Cetakan Keenam. Akademika Pressindo, Jakarta.

Haynes, RJ. 1986. Effects of soil acidification and subsequent leaching on levels of extractable nutrients in a soil. Plant and Soil 95: 327336.

Lal, R. 2009. Soil degradation as a reason for inadequate human nutrition. Food Security 1 (1): 45-57.

Lamb, D, P Erskine, and J Parrota. 2005. Restoration of degraded tropical forest landscape. Science 310: 1628-1632.
Meijerink, AMJ. 1988. Data acquisition and data capture through terrain mapping units. In The Integrated Land and Watersheed Management Information System, Enschede (AMJ Meijerink, RV Carlos, and A Stewart, ed). ITC Publication Journal No. 7.

Pusat Penelitian Tanah dan Agroklimat. 1993. Informasi Penelitian Tanah, Air, Pupuk dan Lahan. Pusat Penelitian Pengembangan Tanah dan Agroklimat, Bogor.

Sumartoyo. 1989. Pendekatan Geomorfologi untuk Kajian Kerentanan Erosi dan Morfokonservasi Daerah Sub DAS Lematang Hulu Lahat, Sumatera Selatan. [Skripsi]. Universitas Gajah Mada, Yogyakarta. [Tidak Dipublikasikan]. 